\title{
The Potential Role of Auxin and Abscisic Acid Balance and FtARF2 in the Final Size Determination of Tartary Buckwheat Fruit
}

\author{
Moyang Liu ${ }^{1,+}\left(\mathbb{D}\right.$, Zhaotang Ma ${ }^{1,+}$, Tianrun Zheng ${ }^{1,+}{ }^{,}$Jing Wang ${ }^{1}$, Li Huang ${ }^{1}$, Wenjun Sun ${ }^{1}$, \\ Yanjun Zhang ${ }^{1}$, Weiqiong Jin ${ }^{1}$, Junyi Zhan ${ }^{1}$, Yuntao Cai ${ }^{1}$, Yujia Tang ${ }^{1}$, Qi Wu ${ }^{1}$, Zizhong Tang ${ }^{1}$, \\ Tongliang Bu ${ }^{1}$, Chenglei $\mathrm{Li}^{1}$, Hui Chen ${ }^{1, *}$ and Gang Zhao ${ }^{2, *}$ \\ 1 College of Life Science, Sichuan Agricultural University, Ya'an 625014, China; lmyyunxi@163.com (M.L.); \\ WaohUncle_Ma@163.com (Z.M.); kobezey@163.com (T.Z.); wj2366zz@163.com (J.W.); \\ 18428385443@163.com (L.H.); sunnan82475@163.com (W.S.); 15227793373@163.com (Y.Z.); \\ Joan541573@163.com (W.J.); zhanjunyi0412@163.com (J.Z.); caiyt410725@163.com (Y.C.); \\ 15984549383@163.com (Y.T.); wuqi@sicau.edu.cn (Q.W.); 3530279123456789@163.com (Z.T.); \\ tlbu@163.com (T.B.); lichenglei1998@163.com (C.L.) \\ 2 College of Biological Industry, Chengdu University, Chengdu 610101, China \\ * Correspondence: chenhui@sicau.edu.cn (H.C.); zhaogang@cdu.edu.cn (G.Z.); Tel.: +86-18981604486 (H.C.) \\ + These authors contributed equally to this work.
}

Received: 24 July 2018; Accepted: 12 September 2018; Published: 13 September 2018

\begin{abstract}
Tartary buckwheat is a type of cultivated medicinal and edible crop with good economic and nutritional value. Knowledge of the final fruit size of buckwheat is critical to its yield increase. In this study, the fruit development of two species of Tartary buckwheat in the Polygonaceae was analyzed. During fruit development, the size/weight, the contents of auxin (AUX)/abscisic acid (ABA), the number of cells, and the changes of embryo were measured and observed; and the two fruit materials were compared to determine the related mechanisms that affected fruit size and the potential factors that regulated the final fruit size. The early events during embryogenesis greatly influenced the final fruit size, and the difference in fruit growth was primarily due to the difference in the number of cells, implicating the effect of cell division rate. Based on our observations and recent reports, the balance of AUX and ABA might be the key factor that regulated the cell division rate. They induced the response of auxin response factor 2 (FtARF2) and downstream small auxin upstream RNA (FtSAURs) through hormone signaling pathway to regulate the fruit size of Tartary buckwheat. Further, through the induction of fruit expansion by exogenous auxin, FtARF2b was significantly downregulated. The FtARF $2 b$ is a potential target for molecular breeding or gene editing.
\end{abstract}

Keywords: Fagopyrum tataricum Gaertn.; abscisic acid; auxin; cell division; embryogenesis; polygonaceae; fruit size; ARF2; SAURs

\section{Introduction}

Increasing fruit yield is one of the primary goals of botanists. Fruit size and fruit number are the two complementary agronomic traits that determine the yield of crop varieties. The size of the fruit affects the economic value. From the beginning of crop domestication, the size of the fruit has been the basis for the selection of varieties. For the plant itself, large fruit reserves have more nutrients, which is conducive to the growth and development of crops, faster germination, and resistance to abiotic stress [1].

Possible factors are reported that affect fruit volume [2]. The volume of fruit is the result of the combination of embryo, endosperm, and pericarp [3]. These tissues originate from maternal 
tissues or different fertilization events (for example, one sperm cell fertilizes diploid central cells to form triploid endosperms, and a second sperm cell fertilizes egg cells to form diploid embryos). These events occur during specific periods of fruit development: cell division occurs primarily at the stage of embryogenesis, whereas cell dilatation occurs more frequently at the stage of filling [4]. In this process, the fertilized egg undergoes a series of cell divisions, leading to different stages of embryonic development (i.e., globular, heart, torpedo, curved cotyledon, and-eventually-mature embryo) [4]. Endogenous hormones play an extremely important role in fruit growth and embryo development. AUX and ABA are the key hormones to control the embryogenesis pattern and promote fruit accumulation in the subsequent filling stage, respectively [5-7]. Various genes involved in different mechanisms control fruit size [8]. Because the size of a fruit is generally primarily related to the initial growth of the embryo rather than to the later growth of the embryo $[3,9,10]$, we focused our attention on embryo and cotyledon differentiation, endosperm development, and cell division in the early stages of fruit development [11].

$A R F s$ are important transcription factors in the plant auxin signaling pathway, which regulate the expression of auxin-related genes in a positive or negative way, thereby regulating the growth and development of plants [12]. By comparing the protein sequences of the members of tomato, Arabidopsis, potato, rice, and grape $A R F$ families, a phylogenetic tree was established, and the $A R F$ family was divided into four branches. Among the branches, the protein intermediate region of the subfamily genes of ARF I a, II b, III, and IV contains an inhibitory domain, and the ARF proteins of these subfamilies are likely transcriptional suppressors $[13,14]$. ARF2 is a member of the ARF I a subfamily. As a potential auxin negative transcription factor, the gene has been cloned in many types of model plants. In Arabidopsis thaliana, ARF2 mutants exhibit regulatory effects on plant growth and development, including plant enlargement and abnormal tissue morphology [15]. ARF2 gene is expressed at many stages of plant growth and development. ARF2 mutants show obvious delayed phenomena in many stages of plant senescence, including flower shedding, leaf senescence, and pod maturation [16]. Some studies find that ARF2 mutation can promote cell division, and the expression period of CYCD3.1 and ant genes related to the cell cycle in stem and rosette of ARF2 mutant lines is prolonged accordingly. These results suggest that $A R F 2$ is an inhibitory factor for cell division and tissue development [17]. ARF2 also mediates the interaction between auxin and other plant hormones. $A R F 2$ and HB33, as novel regulatory factors, play an important role in regulating plant growth in the AUX and ABA pathways [18].

Tartary buckwheat is the only widely cultivated monomeric total-nutrition grain crop. The essential amino acid composition of the seed protein is not only balanced but also the total content is higher than that of primary grain crops [19-21]. With the demand increasing for Tartary buckwheat, understanding the determination of fruit size of Tartary buckwheat has been a key problem. Great differences are found in fruit size among buckwheat varieties, which provide an important genetic resource for understanding how the species regulates fruit size. In this study, we used two Tartary buckwheat varieties with different fruit volumes and similar genetic background and fruit growth cycle to study the factors that lead to different fruit sizes (growth mode, embryo development, cell proliferation) during the development of Tartary buckwheat. Simultaneously, we reported FtARF2 as a potential target for molecular breeding or gene editing. FtARF2 was first identified from the Tartary buckwheat genome and then quantified by reverse transcription-quantitative PCR (RT-qPCR) in Tartary buckwheat varieties with different fruit sizes. Finally, by applying exogenous auxin, FtARF $2 b$ was identified as a potential target for molecular breeding or gene editing.

\section{Results}

\subsection{Morphological Characteristics of Tartary Buckwheat with Different Types of Fruits and Different Growth Patterns}

After the different materials were cultivated under the same conditions, we confirmed that the mature fruits of big Tartary buckwheat (BTB) plants were larger than those of small Tartary 
buckwheat (STB) plants. The mature fruits from BTB were 1.43-fold heavier than those of STB (Figure 1A; Table 1). We also measured the size of mature fruits to determine which two-dimensional axis (i.e., transverse or longitudinal diameter) in the fruits was most affected by the increase in size. The two dimensions both showed an increase in size, with the increase in transverse diameter contributing the most to the increase in fruit size, which resulted in an increase in the size of the final fruit (Table 1). The transverse diameter of the mature fruit of BTB was 1.2-fold longer than that of the STB (Figure 1A; Table 1). Then, the fresh weight and transverse and longitudinal diameters of the two different materials (BTB and STB) were determined from 7 to 30 days after pollination (DAP). We noticed that the growth patterns of the two materials were different. The BTB fruit showed a heavier weight to that of the STB, especially after 13 DAP, increased significantly and remained relatively large throughout the development process (Figure 1B). The growth pattern of the longitudinal diameter of BTB was similar to that of STB (Figure 1C), but the growth pattern of the transverse diameter was different. BTB transverse diameters increased continuously from 7 to 25 DAP and reached the maximum at 25 DAP (Figure 1D). The STB transverse diameters increased from 7 to 19 DAP and reached the maximum at 19 DAP (Figure 1D). Simultaneously, we also found that the growth rate of BTB transverse diameters was higher than that of STB transverse diameters from 7 to 13 DAP (Figure 1D). Therefore, the growth time of the transverse diameters of BTB was not only longer than that of STB but also the growth rate of the transverse diameters of BTB was higher than that of STB transverse diameters at the early stage of fruit development. These growth patterns indicated that the regulatory mechanism(s) conferring the large fruits occurred between 13 and 25 DAP; thus, during the fruit expansion stage.

\subsection{Anatomical Structure of Tartary Buckwheat with Different Fruit Types}

In the early stage of fruit development, the embryo development of the two different materials was clearly different. The development of STB embryos began earlier than that of BTB embryos. At 7 DAP, the embryo of STB had entered the stage of heart embryo, whereas the embryo of BTB remained in the stage of globular embryo (Figure 2A). At 13 DAP, the embryo of BTB entered the heart stage, and STB preferentially formed the torpedo embryo (Figure 2A). After 19 DAP, both materials showed embryos with full cotyledon development, but the cotyledon of BTB was larger than that of STB by size, and the BTB endosperm was larger than the STB endosperm by size (Figure 2B). Further observation of starch granules in the endosperm showed that starch granules in the BTB endosperm were denser by the density than STB endosperm starch granules (Figure 2B). The BTB fruit was larger than that of STB possibly because of the increase in fruit cell number and/or cell expansion. To identify the primary factors, we measured the embryonic cell number and embryonic cell size of the two materials at 19 DAP. The size of STB cells was similar to that of BTB cells, but the number of BTB cells was significantly greater than that of STB cells (Figure 2C). Based on this result and the determination of the final fruit size at maturation between 13 and 25 DAP, we analyzed the number of embryonic cells in the process of embryogenesis. As shown in Figure 3D, at 13 DAP, the number of cells between BTB and STB was similar, although the embryonic development of BTB remained in the heart stage. Then, from 13 to 19 DAP, the rate of proliferation of BTB cells was significantly higher than that of STB cells. After $19 \mathrm{DAP}$, the proliferation rate of the two materials was similar, and the increase almost stagnated. Similar to that of fruit at these time points was the pattern of weight gain rate (Figure 1B). According to the above results, we speculate that the development of the early embryo was too rapid, the cotyledon embryo formed prematurely, the cell division cycle was shortened, and the size of the whole embryo was affected. Simultaneously, the early entry into the cotyledon embryo affected the formation of starch granules in the endosperm, thereby affecting the size of the whole fruit. 
A
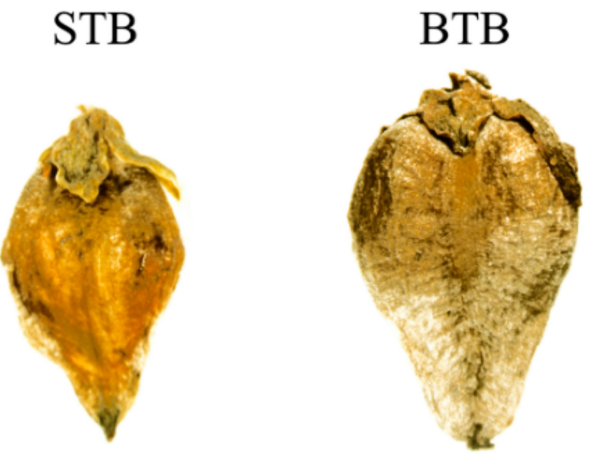

$5.0 \mathrm{~mm}$

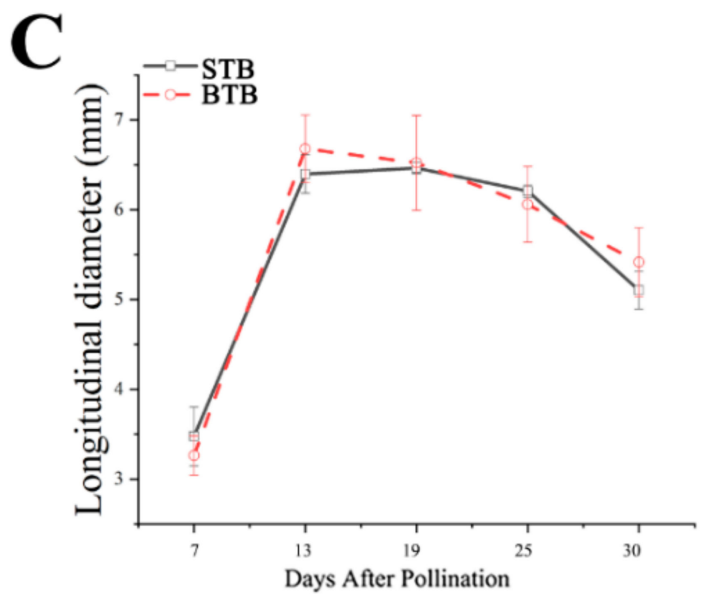

B

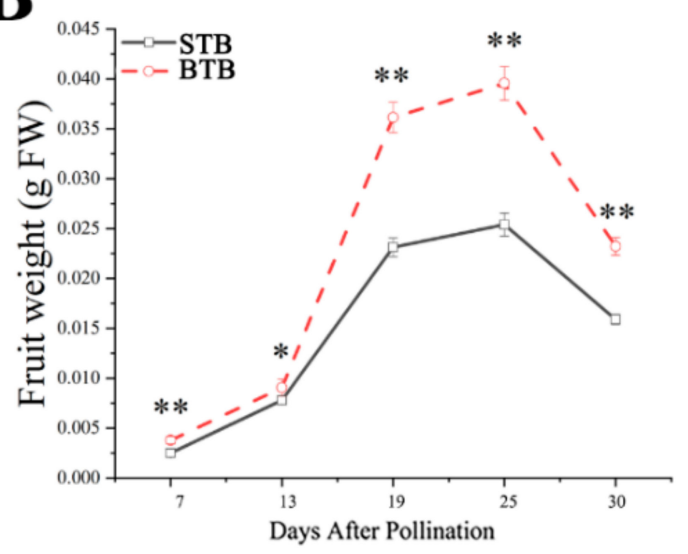

D

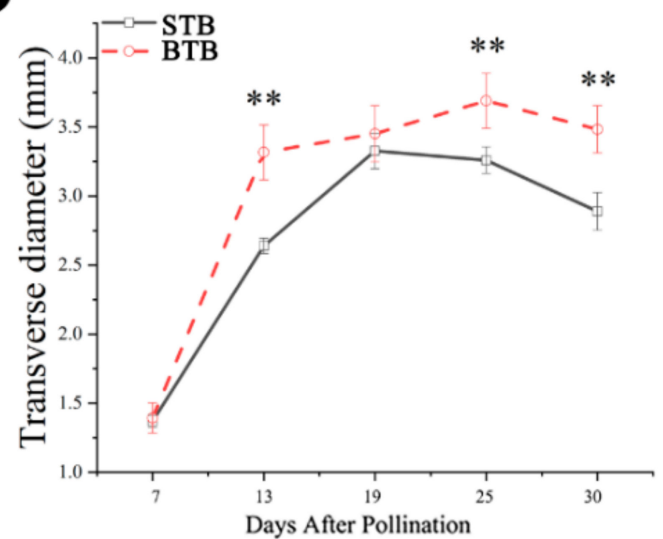

Figure 1. Fruit growth patterns of different accessions of Tartary buckwheat. (A) Pictures of mature fruits of the two accessions. (B) Average fresh weight of one fruit of the two Tartary buckwheat accessions (STB, black squares; BTB, red circles) is plotted against the developmental stages (days after pollination) $(n=5)$. (C) Average longitudinal diameter of one fruit of the two Tartary buckwheat accessions (STB, black squares; BTB, red circles) is plotted against the developmental stages (days after pollination) $(n=5)$. (D) Average transverse diameter of one fruit of the two Tartary buckwheat accessions (STB, black squares; BTB, red circles) is plotted against the developmental stages (days after pollination) $(n=5) ;{ }^{*}$ and ${ }^{* *}$ indicate significant differences $(\alpha=0.05 ; \alpha=0.01$, least significant difference test (LSD)) among treatments, respectively.

Table 1. Plant materials used in this study and their characteristic mature fruit size and weight

\begin{tabular}{cccc}
\hline Materials & Transverse Diameter $(\mathbf{m m})$ & Longitudinal Diameter $(\mathbf{m m})$ & Weight $(\mathbf{g})$ \\
\hline BTB & $3.48( \pm 0.17)$ & $5.42( \pm 0.38)$ & $0.023( \pm 0.00087)$ \\
STB & $2.89( \pm 0.14)$ & $5.10( \pm 0.21)$ & $0.016( \pm 0.00051)$ \\
BTB STB ratio & $120 \%$ & $106 \%$ & $143 \%$ \\
\hline
\end{tabular}


A

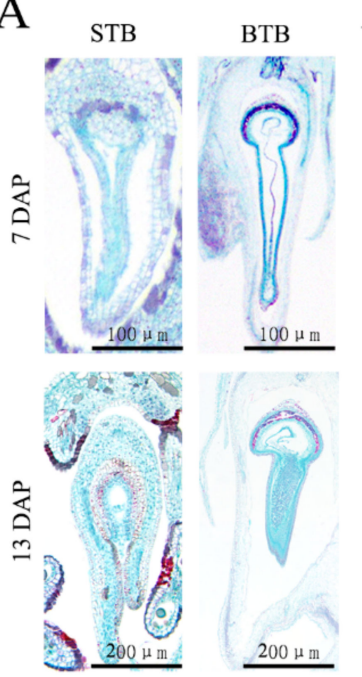

B

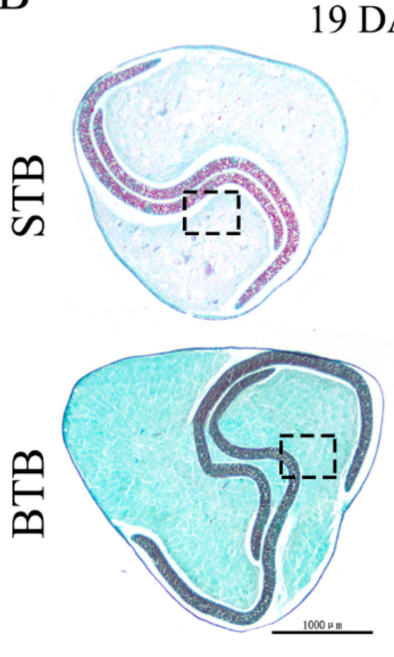

19 DAP
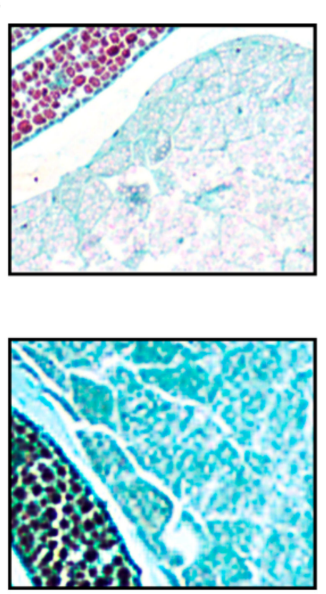

C

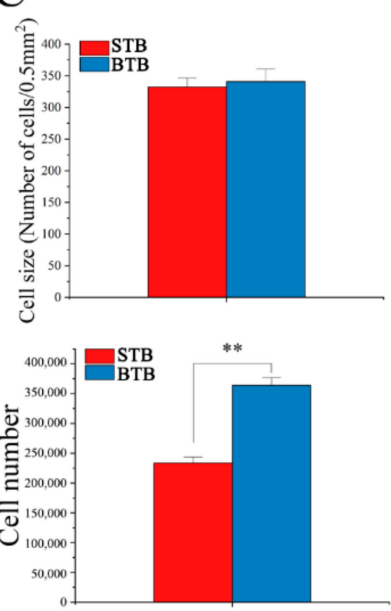

Figure 2. Embryo development of the different accessions. (A) Microscopic longitudinal sections of the different accessions of Tartary buckwheat fruits at 7 and 13 DAP. (B) Microscopic transverse sections of the different accessions of Tartary buckwheat fruits at 19 DAP (right panel is the enlarged view of the boxes in the left panel). (C) Cell size $\left(0.5 \mathrm{~mm}^{2}\right)(n=5)$ and cell number $(n=5)$ in mature fruits of the two accessions; ${ }^{* *}$ indicates significant differences at the level of 0.01 .
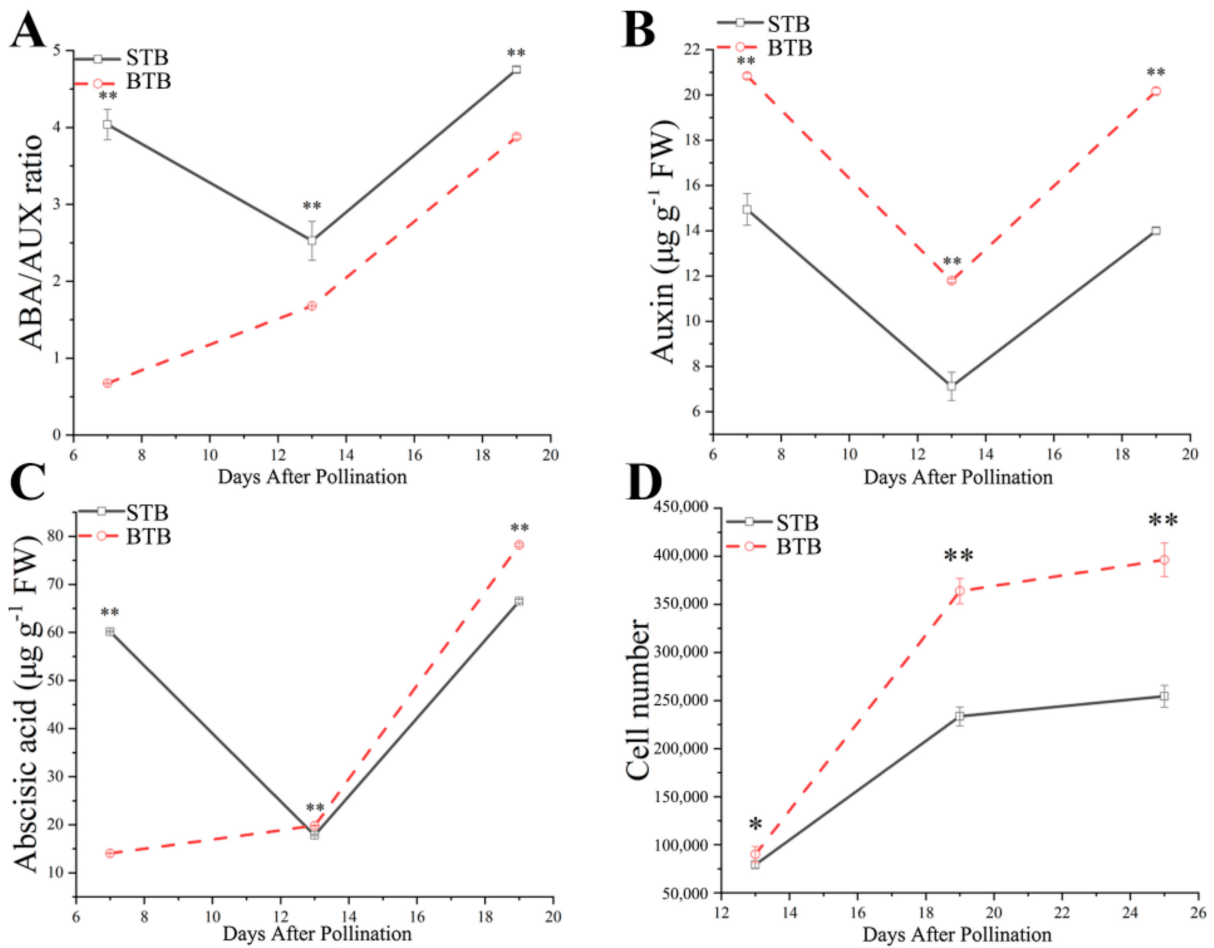

Figure 3. AUX and ABA profiles of the two accessions. (A) The corresponding ratios of ABA to AUX from the above figures are plotted against the developmental age of the fruits (DAP) of STB (black squares) and BTB (red circles). (B) AUX levels of the two Tartary buckwheat accessions (STB, black squares; BTB, red circles) is plotted against the developmental stages (days after pollination) ( $n=3)$; (C) ABA levels of the two Tartary buckwheat accessions (STB, black squares; BTB, red circles) is plotted against the developmental stages (days after pollination) $(n=3)$. (D) Cell proliferation during 13-25 DAP of fruit development (STB, black squares; BTB, red circles) $(n=5)$; standard deviations are indicated in the different panels; ${ }^{*}$ and ${ }^{* *}$ indicate significant differences $(\alpha=0.05 ; \alpha=0.01$, LSD) among treatments, respectively. 


\subsection{AUX and ABA Levels Correlate with the Variation in Fruit Size}

Endogenous hormones play an extremely important role in fruit growth and embryonic development. AUX and ABA are the key hormones to control the embryogenesis pattern and promote the accumulation of storage products during the subsequent filling stage [5,6], which are closely related to the phenomenon of delayed pre-embryonic development and the many starch grains in the endosperm of BTB. Therefore, the contents of total AUX and ABA during fruit development of the two materials were determined quantitatively. Based on determination of AUX and ABA in the fruits from 7 to 19 DAP by high performance liquid chromatography (HPLC), we observed the accumulative patterns of AUX and ABA in the two materials. The results showed that from 7 to 19 DAP, the accumulative pattern of AUX was the same in the two materials (Figure 3B); whereas the ABA accumulation pattern was different (Figure 3C). The ABA content in the fruit of BTB was relatively low at 7 DAP, and the content in fruit increased with time to 19 DAP (Figure 3C). When STB was at 7 DAP, the ABA content of fruit was relatively high, and the content from 7 to 19 DAP decreased first and then increased (Figure 3 C). To summarize, the difference between STB and BTB hormone accumulation models was primarily the difference in ABA accumulation pattern from 7 to 13 DAP. This difference in ABA accumulation patterns led us to compare the ratio of ABA to AUX accumulation from 7 to 13 DAP. We observed that the pattern of BTB and STB was very different, particularly the ratio of ABA to AUX (Figure 3A). The ratio of ABA/AUX in STB was negatively correlated with the fruit development model (Figure 1B) and cell proliferation rate (Figure 3D) from 7 to 13 DAP. From 13 to $19 \mathrm{DAP}$, the rate of ABA/AUX ratio was similar, and the rate of cell proliferation was similar. Therefore, we hypothesized that at the early stage of fruit development (from 7 to 13 DAP), the high ratio of ABA/AUX accelerated the early entry of embryos into the cotyledon embryo stage, and ABA accelerated embryo maturation (or aging). Under the same ratio of ABA/AUX (from 13 to $19 \mathrm{DAP}$ ), the difference in fruit growth power and cell proliferation was presumably due to the response factors of related hormones.

\subsection{Expression of FtARF2 Genes of Tartary Buckwheat with Different Fruit Types from 13 to 19 DAP}

Using protein sequences of the Arabidopsis ARF2 gene as a query, we conducted a BLAST search in the Fagopyum talaricum genome browser and obtained Fagopyum talaricum ARF2 genes (Table 2). Phylogenetic analysis of protein sequences was used to direct the designation of gene names (Figure S1). To investigate the physiological function of FtARF2 genes, real-time PCR was used to detect the time expression of individual members of the genes. Transcript accumulation was assessed for 2 FtARF2 genes in the different types of Tartary buckwheat from 13 to 19 DAP (Figure 4). The results showed that the expression patterns of the FtARF2 genes were similar in the two different types of Tartary buckwheat fruits (Figure 4A,B). The FtARF2 genes expression decreased from 13 to 19 DAP. The expression of FtARF2 $a$ in STB and BTB was lower than that of FtARF2b, but the decrease in FtARF2 $a$ was less than that of FtARF2b (Figure 4A,B). Therefore, FtARF2b had a better negative response than that of FtARF2a; and FtARF2b had more potential than FtARF2a in terms of development (time). We further compared their expression in different types of fruits simultaneously (Figure 4C,D). The results showed that the expression of FtARF2a was similar in the different types of fruits in the same period. The expression of FtARF2b in STB was higher than that in BTB, particularly at 13 DAP (Figure $4 C, D)$. This finding is consistent with our previous results. 

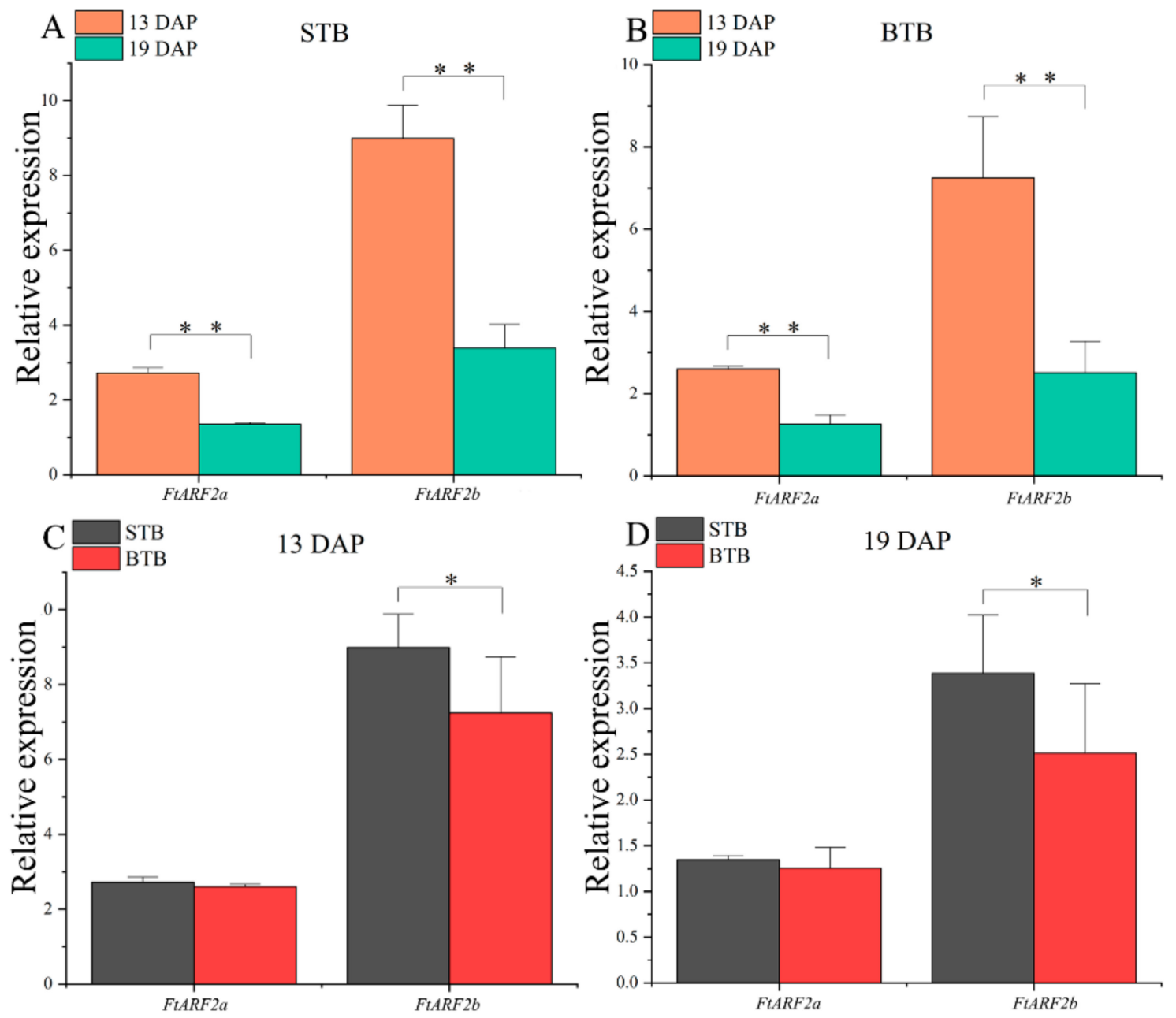

Figure 4. Expression analysis of the two FtARF2 genes in the different accessions of Tartary buckwheat fruits at 13 and 19 DAP. (A) Expression analysis of the two FtARF2 genes in STB fruit at 13 and 19 DAP. (B) Expression analysis of the two FtARF2 genes in BTB fruit at 13 and 19 DAP. (C) Expression analysis of the two FtARF2 genes in the different accessions of Tartary buckwheat fruits at 13 DAP. (D) Expression analysis of the two FtARF2 genes in the different accessions of Tartary buckwheat fruits at 19 DAP. * and ${ }^{* *}$ indicate significant differences at 0.05 and 0.01 levels, respectively.

Table 2. FtARF2 genes encoding ARF proteins along with their molecular details

\begin{tabular}{|c|c|c|c|c|c|c|c|c|c|c|}
\hline Gene & Gene ID & $\begin{array}{l}\text { Protein } \\
\text { Length }\end{array}$ & $\begin{array}{c}\mathrm{Mw} \\
\text { (kDa) }\end{array}$ & pI & Location & Domain & Homologous & E-Value & Similarity & Localization \\
\hline FtARF2.01 & FtPinG0002469700.01 & 766 & 81 & 6.03 & Ft1 & $\begin{array}{c}\text { DBD, } \\
\text { ARF, CTD }\end{array}$ & AtARF2 & $8 \times 10^{-50}$ & 79 & Nucleus \\
\hline FtARF2.02 & FtPinG0005575800.01 & 721 & 85 & 6.03 & Ft2 & $\begin{array}{c}\text { DBD, } \\
\text { ARF, CTD }\end{array}$ & AtARF2 & $1 \times 10^{-42}$ & 79 & Nucleus \\
\hline
\end{tabular}

\subsection{Weight Gain of STB Fruit Induced by AUX}

To further understand the response of FtARF2s to auxin, different concentrations of AUX (40, 70, 100,130 , or $160 \mathrm{mg} \mathrm{L}^{-1}$ ) were sprayed on the whole plants of STB in the bud stage. The fresh weight of mature fruit of STB increased significantly to $0.0164 \mathrm{~g}$ under the action of $100 \mathrm{mg} \mathrm{L}^{-1}$ AUX, which was $103 \%$ of the blank group (0.0159 g) (Table 3). The application of AUX at concentrations less than or greater than $100 \mathrm{mg} \mathrm{L}^{-1}$ had no significant effect on the increase in the weight of the mature fruit of STB and even inhibited the increase in the weight of the fruit. Therefore, $100 \mathrm{mg} \mathrm{L}^{-1}$ AUX was the best choice to increase the weight of STB fruit, as we further studied the expression of FtAFR2 genes in exogenous spraying with AUX. 
Table 3. Effects of IAA on the fruit of STB

\begin{tabular}{ccc}
\hline Materials & IAA Concentration $\left(\mathbf{m g ~ L}^{-\mathbf{1}}\right)$ & Weight $(\mathbf{g})$ \\
\hline 0 (Mock) & $0.01590( \pm 0.00051) \mathrm{ad}$ \\
40 & $0.01594( \pm 0.00041) \mathrm{ab}$ \\
STB & 70 & $0.01482( \pm 0.00075) \mathrm{cd}$ \\
& 100 & $0.01644( \pm 0.00055) \mathrm{a}$ \\
& 130 & $0.01538( \pm 0.00059) \mathrm{bc}$ \\
160 & $0.01456( \pm 0.00060) \mathrm{d}$ \\
\hline
\end{tabular}

Small letter(s) indicate significant differences $(\alpha=0.05$, LSD) among treatments.

\subsection{Expression of the FtARF2 Genes of STB Under AUX Treatment Conditions}

To further study the response of FtARF2 genes to auxin in the early stage of development of Tartary buckwheat, STB was treated with $100 \mathrm{mg} / \mathrm{L}$ exogenous auxin, to promote the fruit weight gain of Tartary buckwheat. The expression of the FtARF2 genes was determined by collecting the fruits in the period regulating fruit volume. We found that the expression of the two FtARF2 genes significantly decreased with fruit development. Compared with the control group, the expression of the FtARF $2 b$ gene in buckwheat fruit treated with exogenous auxin decreased from 13 to 19 DAP, and FtARF2 $a$ also showed the same trend, but which decreased more gradually than that in the control group (Figure 5A,B). Simultaneously, compared with the control group, the expression of FtARF2 genes in buckwheat fruits treated with auxin decreased. The expression of FtARF2a and FtARF2b decreased significantly at 13 DAP, particularly FtARF2b. The expression of FtARF2a at 19 DAP was slightly lower than that of the control group, whereas FtARF2b showed a significant downward trend (Figure 5C,D). To summarize, FtARF2 genes were significantly downregulated during 13 to 19 DAP under the action of exogenous auxin. In particular, FtARF $2 b$ strongly responded to exogenous auxin at 19 DAP. Although the expression of FtARF2a was lower under the action of exogenous auxin, $F t A R F 2 b$ was better than FtARF2 $a$ for the sustained negative response of exogenous auxin and the amplitude of the negative response.
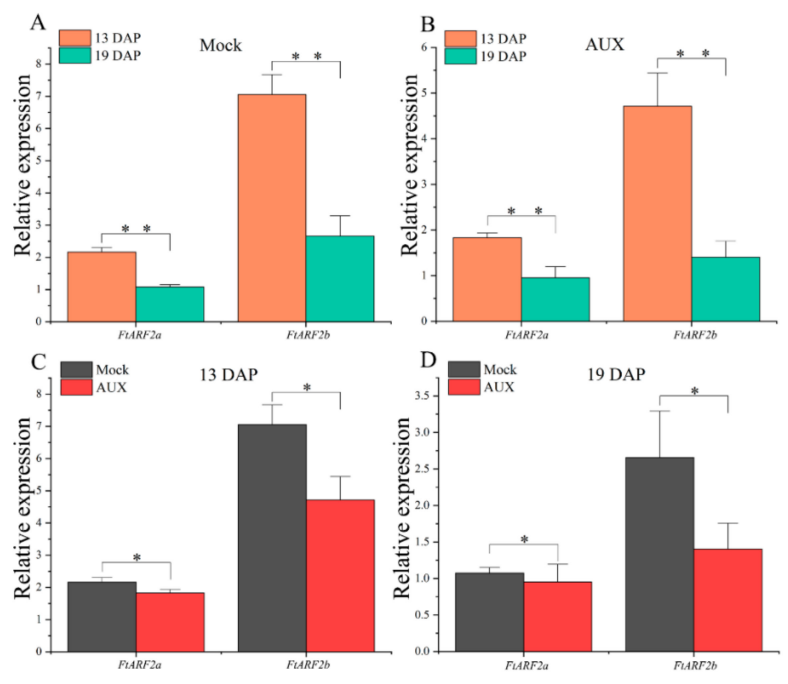

Figure 5. Expression analysis of the two FtARF2 genes in the STB fruits at 13 and 19 DAP under mock and IAA treatments. (A) Expression analysis of the two FtARF2 genes in the STB fruits at 13 and 19 DAP under mock treatments. (B) Expression analysis of the two FtARF2 genes in the STB fruits at 13 and 19 DAP under IAA treatments. (C) Expression analysis of the two FtARF2 genes in the STB fruits at 13 DAP under mock and IAA treatments. (D) Expression analysis of the two FtARF2 genes in the STB fruits at 19 DAP under mock and IAA treatments. ${ }^{*}$ and ${ }^{* *}$ indicate significant differences at 0.05 and 0.01 levels, respectively. 


\subsection{FtARF2 Acts Upstream of Fruit Development Genes}

To understand the effect of FtARF2 on the fruit volume of Tartary buckwheat, we studied the expression patterns of three known downstream genes, auxin/indole acetic acid (Aux/IAAs), gretchen hagen 3 (GH3s), and SAURs [22-24], acting on fruit growth in mock and exogenous auxin-treated plants. Using protein sequences of Arabidopsis Aux/IAAs, GH3s, and SAURs genes as a query, we conducted a BLAST search in the Fagopyum talaricum genome browser and obtained Fagopyum talaricum Aux/IAAs, GH3s, and SAURs genes, respectively (Figures S2-S4). Real-time PCR was used to detect the expression of individual members of the genes. Transcript accumulation was assessed for those genes in the different types of Tartary buckwheat from 13 to 19 DAP (Figure 6). Compared with the control group, the expression of $F t A u x / I A A s$ and FtGH3s genes in buckwheat fruit treated with exogenous auxin was not significantly different (Figure 6A-D), but significantly downregulated FtSAURs genes were detected, including FtSAUR64a, FtSAUR64b, FtSAUR67a, and FtSAUR67b at 13 DAP and FtSAUR40b at $19 \mathrm{DAP}$ (Figure 6E,F). Thus, auxin decreased the expression of these genes.
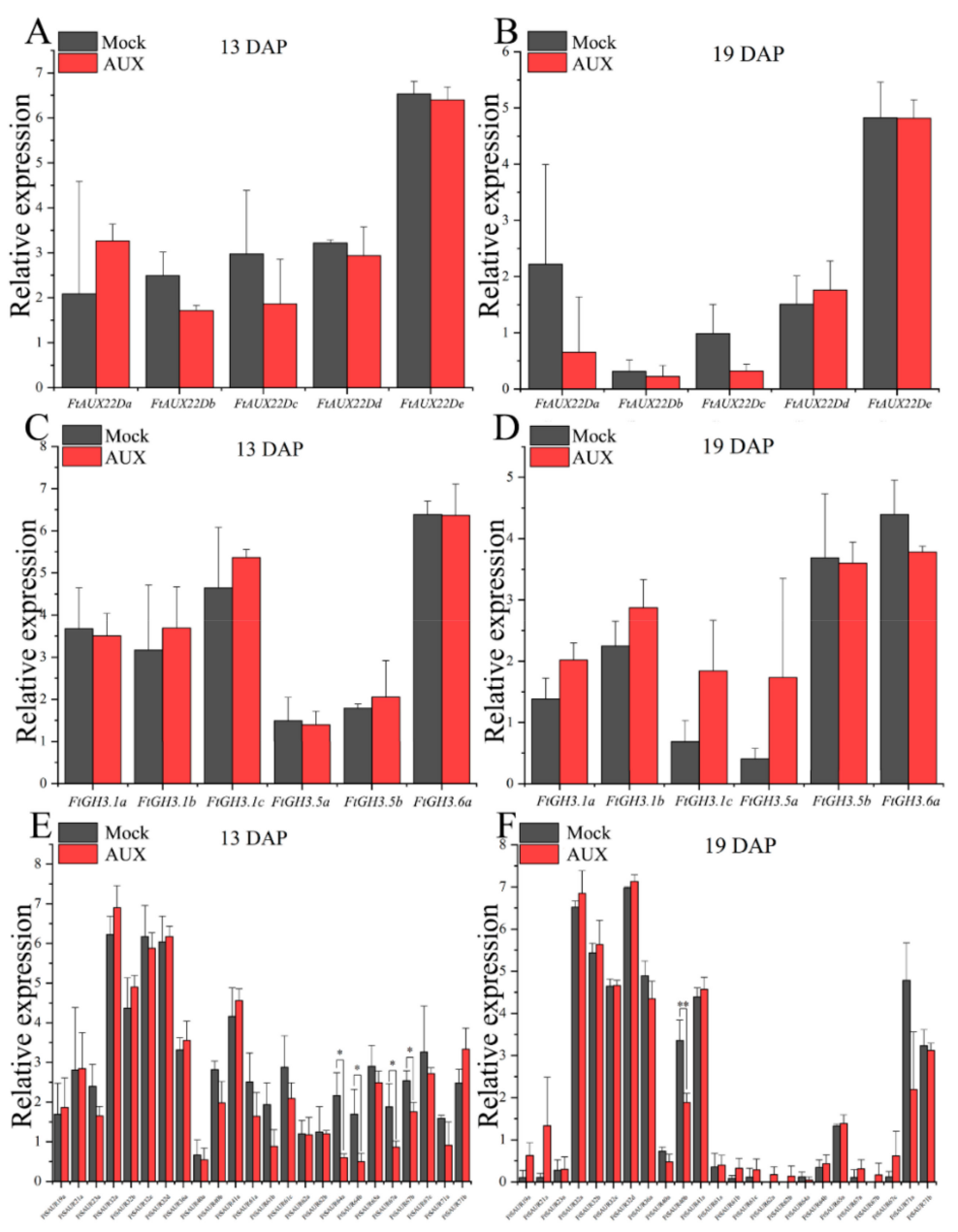

Figure 6. Expression analysis of FtAux/IAAs, FtGH3s, and FtSAURs genes in STB fruits at 13 and 19 DAP under mock and IAA treatments. (A) Expression analysis of $F t A u x / I A A$ genes in STB fruits at 13 DAP under mock and IAA treatments. (B) Expression analysis of FtAux/IAA genes in STB fruits at 19 DAP under mock and IAA treatments. (C) Expression analysis of $F t G H 3 s$ genes in STB fruits at 13 DAP under mock and IAA treatments. (D) Expression analysis of FtGH3s genes in STB fruits at 19 DAP under mock and IAA treatments. (E) Expression analysis of FtSAURs genes in STB fruits at 13 DAP under mock and IAA treatments. (F) Expression analysis of FtSAURs genes in STB fruits at 19 DAP under mock and IAA treatments. * and ** indicate significant differences at 0.05 and 0.01 levels, respectively. 


\section{Discussion}

\subsection{Increased Cell Division During Embryogenesis Leads to an Increase in Fruit Size}

In this study, based on the analysis of Tartary buckwheat resource information registered in the China Crop Germplasm Resources Information System (http:/ /www.cgris.net/), we selected two Tartary buckwheat varieties as research objects, because their fruits represented large buckwheat and small buckwheat (Table 4). Additionally, their genetic backgrounds were similar, and the fruit development cycle was the same. The size of monocotyledonous fruit is related to the degree of endosperm growth $[25,26]$. In dicotyledons, the fruit size primarily correlates with the size of the cotyledons, and the number and size of cotyledon cells are directly related to the final fruit size [27]. We observed that Tartary buckwheat had cotyledons and endosperm in mature fruits, which is different from other common crops. Any difference in fruit size has one of two explanations: large fruit contains more cells, indicating a difference in cell division, or larger cells, indicating the expansion of cells (or the combination of these two phenomena). Cell division is active during fruit development and stops before fruit maturation, and cell proliferation primarily occurs during fruit maturation [8]. Additionally, the size of the fruit is generally primarily associated with the initial growth of the endosperm and not with the later growth of the embryo [3,9-11]. These results prompted us to compare the changes in cell numbers between STB and BTB in the early stages of fruit development. By comparison, we found that the difference in fruit size was explained by the changes in the number of cells in the fruit (Figure 2), which explained the rate of cell division. Studies on embryogenesis of Tartary buckwheat show that cell division in the embryo reaches a peak from 13 to 19 DAP and then tends to stabilize (Figure 3D). Our observation of STB and BTB embryos is consistent with these results, indicating that the embryonic development of BTB was delayed in the heart phase and torpedo, and that more cells potentially divided than those in STB. The analysis of cell proliferation showed that the cell division time of BTB was longer and the cell division rate was higher after pollination than those of STB, particularly at 13 DAP (Figure 3D). Notably, another example of significant delay in fruit development is described in Arabidopsis ARF2 mutants [16]. Some studies find that ARF2 mutation promotes cell division, and the expression period of CYCD3.1 and ant genes related to the cell cycle in stem and rosette of ARF2 mutant lines is prolonged accordingly [17]. These results suggest that ARF2 is an inhibitory factor for cell division and tissue development. For ARF2 mutants, this delay results in increases in time of embryo growth, cell division activity, and-ultimately-fruit size. A similar mechanism might occur in BTB, which was characterized by delayed early embryogenesis and longer cell proliferation than that of STB.

Table 4. Mature fruit size, shape, and weight of the different accessions from Fagopyrum tataricum.

\begin{tabular}{ccccc}
\hline No. & Cultivar & Size & Shape & Weight (g) \\
\hline 1 & 87-23 (F6080) & Big & Peach shape & 0.0257 \\
2 & HEI LI MI QIAO & Big & Long shape & 0.0244 \\
3 & 87-26 (F6245) & Big & Long cone & 0.0232 \\
4 & LIAO QIAO75 HUAO (KU) & Big & Long shape & 0.0231 \\
5 & XI QIAO & Big & Long shape & $\mathbf{0 . 0 2 3 0}$ \\
6 & 87-27 (F6273) & Big & Long cone & 0.0230 \\
7 & HEI ZI QIAO & Medium & Wide & 0.0228 \\
8 & Mai QIAO & Medium & Long shape & 0.0218 \\
9 & 87-14 (F3091) & Medium & Long cone & 0.0218 \\
10 & YUAN ZI QIAO & Medium & Long shape & 0.0214 \\
11 & BIAN ZI QIAO & Medium & Long shape & 0.0207 \\
12 & YANG QU KU QIAO & Medium & Long shape & 0.0203 \\
13 & KU QIAO (TUO YUAN) & Medium & Long shape & 0.0203 \\
14 & XI YANG KU QIAO & Medium & Long shape & 0.0199 \\
15 & SHI CHE E & Medium & Long shape & 0.0196 \\
16 & JIU JIANG KU QIAO & Medium & Long shape & 0.0195 \\
\hline
\end{tabular}


Table 4. Cont.

\begin{tabular}{ccccc}
\hline No. & Cultivar & Size & Shape & Weight (g) \\
\hline 17 & PING DING KU QIAO & Medium & Long shape & 0.0194 \\
18 & MA KU QIAO & Medium & Wide & 0.0193 \\
19 & E LUO WU QIE & Medium & Long shape & 0.0192 \\
20 & KU TIAO ZI & Medium & Long shape & 0.0190 \\
21 & KU BING QIAO & Medium & Wide & 0.0187 \\
22 & KU QIAO MAI & Small & Long shape & 0.0160 \\
23 & MI QIAO & Small & Long shape & $\mathbf{0 . 0 1 6 0}$ \\
24 & ER BAI KU QIAO & Small & Long shape & 0.0158 \\
25 & 88-33 (IV-171) & Small & Short cone & 0.0154 \\
26 & LENG FAN TUAN & Small & Long shape & 0.0151 \\
27 & HEI KU QIAO & Small & Wide & 0.0150 \\
28 & HONG XI KU QIAO & Small & Long shape & 0.0150 \\
29 & MA QIAO & Small & Long cone & 0.0149 \\
30 & HUI CHA KU QIAO & Small & Wide & 0.0148 \\
31 & 82-4-6 & Small & Long shape & 0.0146 \\
32 & XI KU QIAO & Small & Long shape & 0.0140 \\
33 & 82-8-1 & Small & Long shape & 0.0130 \\
34 & LV QIAO & Small & Long shape & 0.0100 \\
\hline \multicolumn{5}{r}{ Bold samples are the test materials. }
\end{tabular}

Although changes in fruit size are the result of cell division and cell expansion, we did not observe changes in cell size area of mature fruit, which indicated that cell division was the primary factor to determine the fruit size of the materials selected in this study.

\subsection{Regulation of Plant Hormones on Cell Division}

Auxin plays an important role in plant growth and development with regulation of the elongation and division of plant cells [28,29]. However, during the development of Tartary buckwheat fruit, a significant positive correlation between auxin and starch was well described [30]. Starch is the primary substance of Tartary buckwheat fruit, which accounts for $70.22 \%$ of the total substance content, and is primarily stored in the endosperm of Tartary buckwheat fruit, which has an important effect on the size of fruit [31]. To date, few attempts have been conducted to correlate auxin with cell division in the embryonic development of Tartary buckwheat. Arabidopsis thaliana ARF2, a growth hormone responsive gene, is likely a negative regulator of cell division. The mutation of ARF2 leads to an increase in seed size. This increase suggests that ARF2 is an inhibitor of cell division and tissue development [17]. In tomato, the overexpression vector of SlARF2 gene was constructed, and the overexpression of the SlARF2 gene significantly increased the seed setting rate and reduced the fruit size and weight [32]. These results led us to compare the IAA concentrations of STB and BTB from 7 to 19 DAP and to compare their AUX accumulation patterns; and we found a positive correlation between AUX concentrations and cell division or final seed size. In fact, the concentration of auxin alone might not be sufficient to prevent cell division. Auxin acts as a starting or opening switch and through a secondary regulator. Reducing auxin concentration alone (i.e., removing the on switch) does not reduce other hormones. Based on this assumption, a second 'off' switch may be needed to accurately define the time frame for cell division. ABA helps fruits accumulate nutrients during embryonic development, and ABA promotes the absorption of sugar in tomato, strawberry, and citrus [33-35] and participates in fruit growth and maturation [36,37]. According to these reports, a small amount of ABA produced from the mother source accumulates before the cell division stops, which may strengthen the concept of ABA as the second closing switch for cell division. Whereas some plants have two ABA peaks during fruit development, others have only one broad peak [38]. Currently, ABA in Tartary buckwheat fruit is negatively correlated with starch and flavonoids contents [30], but nothing else is known. Mechanically, ABA inhibits cell division in two ways. First, ABA induces 
the expression of cyclin dependent kinase inhibitor (ICK1), which leads to block of the cell cycle [39]. For ABA, which also controls the size of the final seed, the second mechanism is to activate the proliferation inhibitor DA1, which is an inhibitory factor of cell proliferation [2]. Based on our research results and related studies, we hypothesized that the high ratio of ABA to IAA at the end of embryonic development (approximately $13 \mathrm{DAP}$ ) would result in the division of active cells and be related to the final seed size. This hypothesis was supported by the similarity between the ABA/IAA ratio and fruit volume expansion curve that occurred before 13 DAP (Figure 1B,D and Figure 3A). Compared with $\mathrm{BTB}$, the ABA/IAA ratio of STB was downregulated, whereas that of $\mathrm{BTB}$ was upregulated. The growth rate of BTB before 13 DAP was much higher than that of STB. After 13 DAP, although the ABA/IAA ratio pattern tended to be the same, we found that the proliferation patterns of STB and BTB cells were very different. As shown in Figure 3D, the proliferation rate of BTB was much higher than that of STB after 13 DAP. At the end of embryonic development (after 13 DAP), the developmental rate of BTB was different from that of the STB fruit, primarily in terms of weight (accumulation of storage substances). A growth hormone cannot act directly on the target gene and is regulated by binding to the receptor [40]. Additionally, ARF2 also mediates the interaction between auxin and other plant hormones. ARF2 and HB33, as novel regulatory factors, play an important role in regulating plant growth in the auxin and ABA pathways [18]. We speculate that this phenomenon is associated with the signal transduction pathway of related hormones.

\subsection{ARF2s and Their Downstream SAURs Regulate the Fruit Volume of Tartary Buckwheat at the End of Embryo Maturation}

In the current research, the cell signal transduction pathway of plant physiological response to auxin had both a direct mechanism and molecular regulation. A series of genes involved in auxin regulation of transcription include three families of genes (Aux/IAAs, GH3s and SAURs), which contain a conserved sequence "TGTCTC" upstream of their promoters, which are called AuxREs [41,42]. ARFs are a class of transcription factors that can recognize and bind to AuxREs and regulate the expression of auxin responsive genes [41]. In Arabidopsis thaliana, ARF2 mutants exhibit regulatory effects on plant growth and development, including plant enlargement and abnormal tissue morphology [15]. In this study, we identified two FtARF2 genes from the Tartary buckwheat genome (Figure S1). The expression of FtARF2 genes was lower in BTB than that in STB and decreased with fruit development in both STB and BTB. The two FtARF2 genes were negatively correlated with fruit size and development. In Arabidopsis thaliana, ARF2 is an inhibitory factor for cell division and tissue development [17]. Molecular breeding and gene editing require knowledge of specific genes expressed at key stages of growth and development. Because of the existence of many genes in a polygene family, the knowledge of differential expression of individual gene family members has been proven to be crucial [43]. To understand the difference of the two FtARF2 genes in regulating Tartary buckwheat fruit volume, the volume of STB fruit was increased by exogenous auxin. The expression of FtARF2 genes was significantly downregulated compared with that of the control group, and negative regulation of the two FtARF2 genes on the fruit volume of Tartary buckwheat was determined. Based on their positive response, FtARF2 $b$ was established as a potential target for Tartary buckwheat breeding. Simultaneously, we measured the expression of the downstream genes of ARFs (GH3s, AUX/IAAs, and SAURs) between exogenous auxin and blank groups. FtGH3s and FtAUX/IAAs did not show a significant difference, whereas FtSAUR64a, FtSAUR64b, FtSAUR67a, FtSAUR67b, and FtSAUR40b in the FtSAURs showed significant downregulation. The SAURs gene family is unique to plants and the largest family of auxin response factors, which widely exist in various plants [44-47]. In Arabidopsis thaliana, AtSAUR41 may be related to the size of cells in the resting center and cortex and the transport of auxin and may also be involved in the response to development and environmental signal processes [48]. In rice, OsSAUR39 inhibits the synthesis and transport of auxin [49]. Notably, although OsSAUR39 and AtSAUR63 are highly homologous, their effects on auxin transport are different. In our results, the significantly expressed FtSAURs genes-including 
FtSAUR64a, FtSAUR64b, FtSAUR67a, FtSAUR67b, and FtSAUR40b -were downregulated between exogenous auxin and blank groups. However, whether these downstream FtARFs target genes were involved in the auxin signaling pathway is uncertain.

\subsection{Model of Fruit Expansion of Tartary Buckwheat Development: A Time Consideration}

In our model, from fertilization to embryo maturation, the expansion of fruit volume is from the continuous division of embryonic cells, which is strongly influenced by hormones, which may be due to the fertilization potential of plants themselves. The premature maturation of the embryo reduces the cycle of cell division and affects the accumulation of storage materials in later stages, thereby affecting the final volume of the fruit. The balance of AUX and ABA may be the key factors to regulate the cell division cycle. ARF has three potential target genes (AUX/IAA, GH 3 , SAUR) in the hormone regulation pathway [22-24,50,51]. In Tartary buckwheat, through the response of $A R F 2$ and downstream SAURs in the hormone signaling pathway, the result is the continuous expansion of fruit volume and accumulation of storage materials. However, whether these downstream FtARFs target genes (FtSAURs) are involved in the auxin signaling pathway is uncertain. To confirm the regulation mechanism of the entire pathway on the fruit volume of Tartary buckwheat, the downstream genes require further study (Figure 7).

Overall, Tartary buckwheat fruit size is undoubtedly dependent on embryonic cell division; nevertheless, significant input is required from several other hormone signaling pathways. The unique role of FtARF2 in this complex interaction may be the ability to integrate signals, thereby prolonging the cycle of embryonic development, increasing the cycle of cell division and increasing the accumulation of storage materials in fruit tissue.
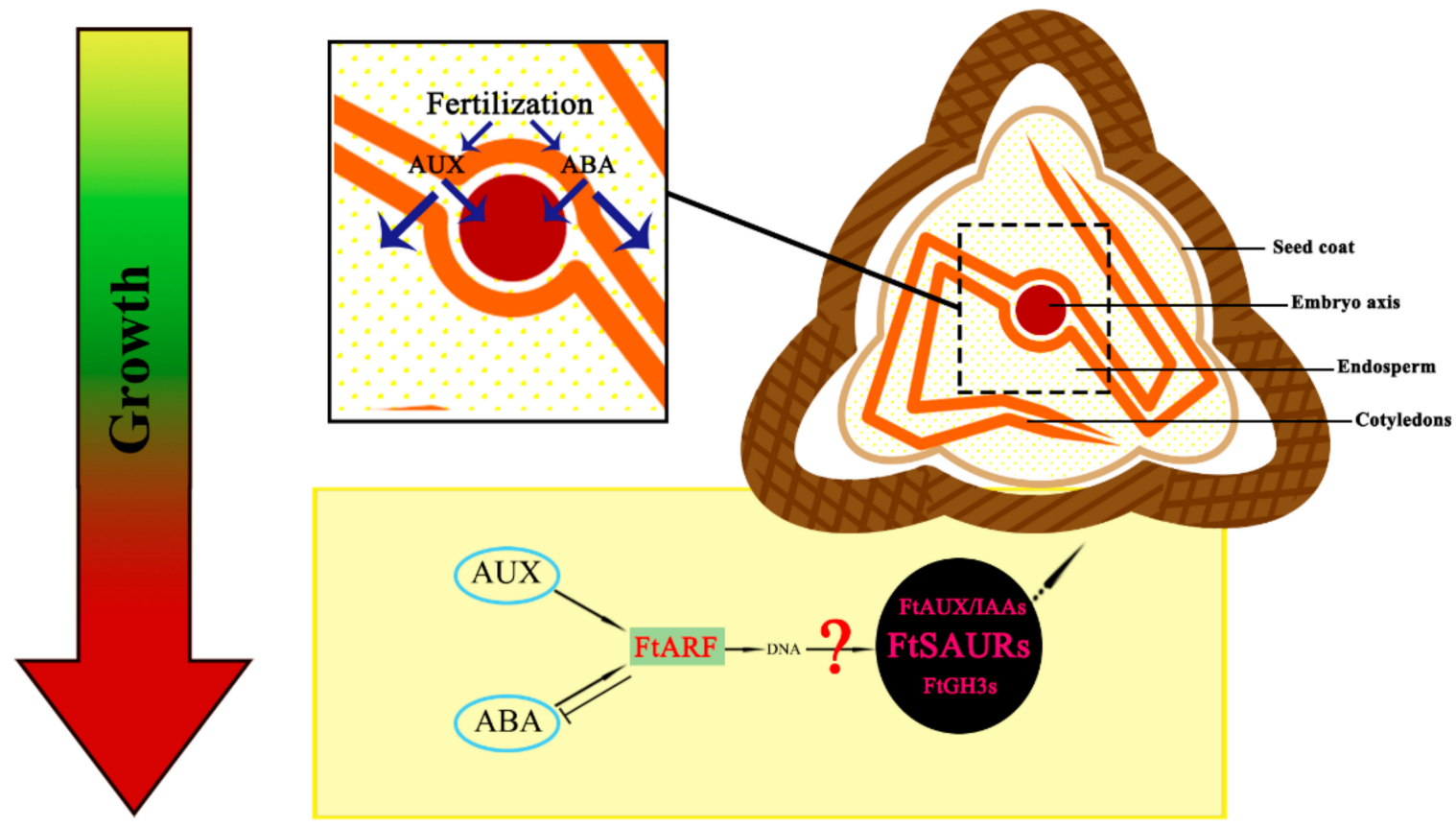

Figure 7. A model of Tartary buckwheat development. The diagram shows the effects of AUX and ABA on embryos shortly after fertilization. Caused by fertilization, the accumulation of AUX and ABA in embryos causes cell division, as shown by the two blue arrows. Induced enlargement is likely to be indirect, through an additional factor, which acts as an inhibitor of expansion. FtARF2 acts as a negative regulator to reduce the expression of unknown expansion inhibitors. This activates the expression of several "master" regulatory factors and downstream enlargement genes. FtARF2 apparently receives signals from at least two hormone pathways, including those of AUX and ABA, and its activity is affected by exogenous AUX. 


\section{Materials and Methods}

\subsection{Plant Material}

In 2017, two types of Tartary buckwheat fruits (STB, MIQIAO; BTB, XIQIAO) were collected at the experimental field of the College of Life Science, Sichuan Agricultural University (Lat. $29^{\circ} 97^{\prime} \mathrm{N}$, $102^{\circ} 97^{\prime}$ E, Alt. 580 m), Ya'an, Sichuan, China. Over the past six years, these buckwheat types were introduced into the field and grown in the same ecological environment and cultivation conditions. We observed the development of fruits from anthesis until maturation in April-May 2017. Fruits were collected manually every two days from the beginning of the fruit to maturity, covering a total range of 30 days, and the size and weight of developing fruits were measured. For phytohormone analysis, fruits at five developing stages $(7,13$, and 19 DAP) were collected from the same individual, and the fruits of the same developing stage were collected from three replicate plants. The samples were flash frozen in liquid nitrogen and stored at $-80{ }^{\circ} \mathrm{C}$ for further use.

\subsection{Light Microscopy}

After being dyed by the Safranine and Fast Green double staining method, the samples above were embedded in paraffin and cut in $2 \mu \mathrm{m}$ sections with a Leica RM2235 paraffin machine (Leica Instruments, Nussloch, Germany). Images of sections were photographed with an Olympus IX83 light microscope (Tokyo, Japan).

\subsection{Counting Total Number of Cells in Mature Fruits}

The fruits were crushed and soaked in water, the fruit coat was removed and the embryo was primarily separated. Four fruits were chopped with a blade and added to a cell wall digestive enzyme mixture of $1 \mathrm{~mL}$ (cellulase Onozuka R10 1\%, $0.45 \mathrm{M}$ sorbitol, $1 \mathrm{mM} \mathrm{KH}{ }_{2} \mathrm{PO}_{4}, 10 \mathrm{mM} \mathrm{MgCl}, 20 \mathrm{mM}$ MES pH 5.6, 0.4\% Macerozyme R10 (phytotechnology, Lenexa, KS, USA)). The samples were incubated at $37{ }^{\circ} \mathrm{C}$ for $24 \mathrm{~h}$, with a regular smooth vortex. After $24 \mathrm{~h}$ of culture, $0.5 \mathrm{~mL}$ of cell wall digestive enzyme mixture was added, followed by incubation for $24 \mathrm{~h}$ to obtain a uniform dispersed cell mixture. The cells were then diluted to $2 \mathrm{~mL}$ and counted on a glass slide in a blood cell counter chamber with $50 \mu \mathrm{L}$ (Fisher biotech, Pittsburg, PA, USA). According to this value, the total number of cells in $2 \mathrm{~mL}$ was calculated, corresponding to the total number of cells in four fruits, which was then divided by 4 to obtain the number of cells in each fruit.

\subsection{Counting Number of Cells in a Given Area (Cell Size)}

Mature fruits were crushed with $\mathrm{H}_{2} \mathrm{SO}_{4}$ for $10 \mathrm{~min}$, washed repeatedly with water, and then soaked for $16 \mathrm{~h}$, put into $20 \%$ sucrose solution for $2 \mathrm{~h}$, incubated for $16 \mathrm{~h}$, and embedded in OCT embedding solution (Olympus IX83; Japan). A $15 \mu \mathrm{m}$ slice was placed in a freeze-microshearing apparatus (Leica, Buffalo Grove, IL, USA), stained in toluidine blue solution, and then washed with water, and the images were collected from the same position and plane at the same magnification. The number of embryonic cells was calculated in a particular area $\left(0.05 \mathrm{~mm}^{-2}\right)$.

\subsection{Phytohormone Analysis}

Precisely weighed, approximately $0.5 \mathrm{~g}$ of fresh sample was ground in liquid nitrogen. The powders were homogenized in $10 \mathrm{~mL}$ of $80 \%$ methanol, followed by stirring overnight at $4{ }^{\circ} \mathrm{C}$. Subsequently, this suspension was centrifuged at $12,000 \mathrm{rpm}$ for $10 \mathrm{~min}$ under refrigeration $\left(4^{\circ} \mathrm{C}\right)$. The supernatant was collected, and $5 \mathrm{~mL}$ of $80 \%$ methanol was added to the residue. Similarly, the supernatant was collected after centrifugation. The pooled supernatant $(\sim 15 \mathrm{~mL})$ was flash evaporated at $36{ }^{\circ} \mathrm{C}$ to no methanol $(\sim 3 \mathrm{~mL})$. The distilled bottle was washed with $5 \mathrm{~mL}$ of ultrapure water. Then, the rinse was combined with the residual liquid $(\sim 3 \mathrm{~mL})$. The solution was decolorized with $15 \mathrm{~mL}$ of diethyl ether three times, and the ether phase was abandoned. Aqueous phase was 
collected and was basified to $\mathrm{pH} 8.0$ with $0.1 \mathrm{M} \mathrm{Na}_{2} \mathrm{HPO}_{3}$. The basified extract was kept on a shaker for $30 \mathrm{~min}$ with $50 \mathrm{mg}$ of polyvinylpyrrolidone at $4{ }^{\circ} \mathrm{C}$, which then was centrifuged at $12,000 \mathrm{rpm}$ for $10 \mathrm{~min}$. The supernatant was collected and was acidified to $\mathrm{pH} 3.0$ with $0.2 \mathrm{M}$ citric acid. The solution was partitioned three times against $5 \mathrm{~mL}$ of ethylacetate, and the aqueous phase was discarded. The pooled ethylacetate phase $(\sim 15 \mathrm{~mL})$ was flash evaporated at $36^{\circ} \mathrm{C}$ to near-dryness. The residue was dissolved in $1 \mathrm{~mL}$ of methanol [52-54].

The sample was filtered through a nylon 66 filter $(25 \mathrm{~mm}$ diameter, $0.45 \mu \mathrm{m}$ pore size) before injection for high-performance liquid chromatography (HPLC). HPLC analysis was performed on an Agilent 1260 system using a C18-ODS $(3.5 \mu \mathrm{m} \times 150 \mathrm{~mm} \times 4.6 \mathrm{~mm})$ column (Agilent, Santa Clara, CA USA) and a UV/VIS detector. Injection volume of $10 \mu \mathrm{L}$, column temperature of $35^{\circ} \mathrm{C}$, flow rate of $1 \mathrm{~mL}$ $\mathrm{min}^{-1}$, and run time of $10 \mathrm{~min}$ were maintained for all analyses. The system was calibrated with external standards of AUX and ABA. For detecting these compounds, the separation was performed with a mixture of methanol and distilled water containing $0.6 \%$ acetic acid $(V: V=50: 50)$ with the following isocratic elution. The eluent was scanned at $257 \mathrm{~nm}$.

\subsection{AUX Treatment of STB}

In the bud stage, Tartary buckwheat with a similar growth state were sprayed once with 40, 70, 100,130 , or $160 \mathrm{mg} \mathrm{L}^{-1}$ of indoleacetic acid (IAA), and the same amount of water was sprayed as the control (Mock). When fully ripe, the weight of the fruits was measured. At 13 and $19 \mathrm{DAP}$, the fruit samples were rapidly frozen in liquid nitrogen and stored at $-80^{\circ} \mathrm{C}$ for further use.

\subsection{Gene Identification and Phylogenetic Analysis}

The Tartary buckwheat genome was downloaded from the Tartary Buckwheat Genome Project (TBGP; http://www.mbkbase.org/Pinku1/). The ARF2 gene of Tartary buckwheat were identified by BLASTP search (https:/ / blast.ncbi.nlm.nih.gov/Blast.cgi). All known Arabidopsis ARF2 gene was used to query the initial protein on TBGP website, and the candidate genes were identified by BLASTP search at a score value of $\geq 100$ and $e$-value $\leq 1 \times 10^{-10}$ [55]. The sequence length, molecular weight, isoelectric point, and subcellular localization of the identified FtARF2 protein were obtained by using the tools of ExPasy website (http:/ / web.expasy.org / protparam/). The phylogenetic trees were inferred using neighbor-joining (NJ) method of Geneious R11, with the following parameters: Jukes-Cantor model, global alignment with free end gaps, and Blosum 62 cost matrix. ARF2 protein sequences from Arabidopsis thaliana were downloaded from UniProt database (https:/www.uniprot.org). FtAux/IAAs, FtGH3s and FtSAURs were obtained in the same procedure.

\subsection{Real-Time PCR Confirmation of Differentially Expressed Genes}

Quantitative real-time PCR analysis was performed to confirm the expression pattern of each identified gene. The corresponding sequences of these genes were obtained from the Tartary buckwheat (Pinku1) genome sequence database (http:/ / www.mbkbase.org/Pinku1/). The RT-qPCR primers were designed according to the transcript sequences of these genes using Primer3 software (http://frodo.wi.mit.edu/) (Table 5). The FtH3 gene was used as the internal control. RT-qPCR experiments were replicated at least three times.

First-strand cDNA was synthesized from $1 \mathrm{mg}$ of DNase I-treated RNA samples in a $40 \mu \mathrm{L}$ reaction solution with random primers, using a PrimeScript RT Reagent Kit with gDNA Eraser (TaKaRa, Tokyo, Japan). Standard RT-qPCR was performed using SYBR Premix Ex Taq II (TaKaRa, Tokyo, Japan) on a CFX96 Real Time System (BioRad, Hercules, CA, USA). Data were analyzed by the $2^{-(\Delta \Delta C t)}$ method to obtain relative mRNA expression data [56]. 
Table 5. Primers of sequences.

\begin{tabular}{|c|c|c|}
\hline Gene ID & Forward Primer $\left(5^{\prime}-3^{\prime}\right)$ & Reverse Primer $\left(5^{\prime}-3^{\prime}\right)$ \\
\hline FtARF2.01 & ACCTTCCGTTTCTCCACTGACA & GACCCTTGATAATGATAACCCACTT \\
\hline FtARF2.02 & AGACTTGTGGCTGGTGACGCT & GCTAGATATGACTGACGAGGGAACT \\
\hline FtGH3.1a & AAGTTGGTGGACATGGTTGACG & TGCGGAGCAGAGTTGTGGAA \\
\hline FtGH3.1b & ТТССТССАССТТСАТТАСССG & GATACСТTCСТСССАGTTCTCСТT \\
\hline FtGH3.1c & CGGAACTCGCTGACTTTATCATATC & AGGGAGACCACCGCTGTAGAA \\
\hline FtGH3.5a & CGTTGTGCTTCCTCAAATCGG & TCGCCAACCTCAACCTCAGTC \\
\hline FtGH3.5b & CGGACTCGTACCAAAGCATGT & CTTGATAGCACGAATGAACCCA \\
\hline FtGH3.6a & AGATGCGTCAAGTTCAAGCCA & TGCTTATGACCAGGAACCCACT \\
\hline FtSAUR19a & TCAAAGCCATACTCCTCTTCAGC & TATGGTGGGGCTCGAAGGA \\
\hline FtSAUR21a & GCACTTTGCGGTGTATGTAGGC & TTGTTCATCACAGGGAATGGTTAG \\
\hline FtSAUR23a & GGGTGGATGGGTATTTGGGTG & GCCGCCTTGAGGAGGTTGAT \\
\hline FtSAUR32a & CGATTACGATCCCTTGCCATG & TCAAGCCCTAAAACACCCAACA \\
\hline FtSAUR32b & GAGAGGAGATGCGGCGATTC & CGAAGTACGCCTTTCTGCTGG \\
\hline FtSAUR32c & ATGGCGATTATGCGAAAGCT & ACGATCACCGGAACATACCCT \\
\hline FtSAUR32d & GGTTTCTTATTCCGACTCAGTTCAT & GAATCTCССТTAAACAATCTGGCT \\
\hline FtSAUR36a & GTCATTCCGAGGTCACCAACAA & AACCCACGGCGGCTTTATG \\
\hline FtSAUR40a & GGACACGAAGCAGAGGAGCA & TTGAGCGACCAAGAACTGAACG \\
\hline FtSAUR40b & ATCTGGCGGTTGATGTGGG & GATACGGGGCAAGGGATAGTG \\
\hline FtSAUR41a & ATTGGACATCCGTCTATTATTGCTC & TAATCTGCCTGAAAGAGTCCACG \\
\hline FtSAUR61a & TTGCCTTCTGTTATCTCAACCACC & CATACCTTTGCTTATCСТCATCGTC \\
\hline FtSAUR61b & TTCCGTTTGCCCTCTGTGAT & GTAAGACAGCGGCACCACATAA \\
\hline FtSAUR61c & TGAGAAGGGCCAGTTTGTCGT & ACTTGCCAGCCCAAACTCTTC \\
\hline FtSAUR62a & TTACACTTCCСTTGTCTTATCTCGG & GGATCAATGCTTGCTCTAGTTCTCT \\
\hline FtSAUR62b & GAGAAGTAACAACACCAAGCAATCA & ATAAGACAAGGGAAGTGTAAAGCGT \\
\hline FtSAUR64a & GAAGAGTTTGGGTTGGTTGGTG & GACACAATCAACGCTTCTTCCAA \\
\hline FtSAUR64b & ATGGCAGAAGAGGAGTTTGGATT & GAGTTCTCTAGCTGCGTTCCGAT \\
\hline FtSAUR65a & ACTTTGTGGTCTACACCGCTGAT & ААСТССТССТCСGCCATTCTA \\
\hline FtSAUR67a & GCAGTGGCAAGTAGGAAGAGGA & GAGATTTGAGATACACCAAGGGAAG \\
\hline FtSAUR67b & CCAAGGAGCAACAGCACCAA & CAAАСТССТСТTCCGССАТTCT \\
\hline FtSAUR67c & TTGGCAAGAAAGTGGAGAAAGC & CCGTGTAGACCATAAACTGACCCT \\
\hline FtSAUR71a & CATTTCCAAGAAGCAACAACACC & TCСАААСТССТСТТСТGССАТТ \\
\hline FtSAUR71b & CAACAGCACCAАCAААТСАТСААС & CAAACTCСТCTTCGGCCATTC \\
\hline FtAUX22Da & GTGTTGGAAAGCATGTTTAAGGTG & CGAAGCCTCTTACACGACGACA \\
\hline FtAUX22Db & AGTGAGCTACTAGAGGCATTGGAAG & CCACGGAACATCACCAACAAG \\
\hline FtAUX22Dc & CAAGGCTTACAAGAGCTACATCGA & AACATTTCCCACGGCACATC \\
\hline FtAUX22Dd & GGATCGACCGACGACCACTT & GCCATCCAACTATTTGTGCCTT \\
\hline FtAUX22De & AGATCAACACTCAACCCTCTGCTT & GCTCCGTCCATGCTTACTTTCAC \\
\hline FtH3 & GAAATTCGCAAGTACCAGAAGAG & CCAACAAGGTATGCCTCAGC \\
\hline
\end{tabular}

\subsection{Statistical Analysis}

All the data were analyzed by analysis of variance using the Origin Pro 2018b (OriginLab Corporation., Northampton, MA, USA) statistics program, and the means were compared by the least significant difference test (LSD) at the 0.05 and 0.01 level of significance.

Supplementary Materials: Supplementary materials can be found at www.mdpi.com/1422-0067/19/9/2755/s1.

Author Contributions: M.L. planned and designed the research, analyzed data and wrote the manuscript. Z.M., T.Z., J.W., L.H., W.S., Y.Z., W.J., J.Z., Y.C., Y.T., Q.W., Z.T., T.B., and C.L. performed the experiments. G.Z. contributed the plant materials. H.C. supervised the research. M.L., Z.M., and T.Z. contributed equally.

Funding: This research was supported by the National Natural Science Foundation of China (31500289).

Acknowledgments: We are very grateful to the editor and reviewers for critically evaluating the manuscript and providing constructive comments for its improvement.

Conflicts of Interest: The authors declare no conflict of interest.

\section{Abbreviations}

ABA

abscisic acid

ARF2

auxin response factor 2

AUX

auxin 


$\begin{array}{ll}\text { Aux/IAAs } & \text { auxin/indole acetic acid } \\ \text { BTB } & \text { big Tartary buckwheat } \\ \text { DAP } & \text { days after pollination } \\ \text { HPLC } & \text { high performance liquid chromatography } \\ \text { GH3s } & \text { Gretchen Hagen 3 } \\ \text { IAA } & \text { indoleacetic acid } \\ \text { ICK1 } & \text { cyclin dependent kinase inhibitor } \\ \text { RT-qPCR } & \text { reverse transcription-quantitative PCR } \\ \text { SAURs } & \text { small auxin up RNAs } \\ \text { STB } & \text { small Tartary buckwheat }\end{array}$

\section{References}

1. Tweddle, J.C.; Dickie, J.B.; Webb, C.O.; Moles, A.T.; Ackerly, D.D.; Westoby, M. A Brief History of Seed Size. Science 2005, 307, 576-580.

2. Li, N.; Li, Y. Ubiquitin-mediated control of seed size in plants. Front. Plant Sci. 2014, 5, 332. [CrossRef] [PubMed]

3. Sundaresan, V. Control of seed size in plants. Proc. Natl. Acad. Sci. USA 2005, 102, 17887-17888. [CrossRef] [PubMed]

4. Goldberg, R.B.; Paiva, G.D.; Yadegari, R. Plant Embryogenesis: Zygote to Seed. Science 1994, 266, 605-614. [CrossRef] [PubMed]

5. Chandrasekaran, U.; Xu, W.; Liu, A. Transcriptome profiling identifies ABA mediated regulatory changes towards storage filling in developing seeds of castor bean (Ricinus communis L.). Cell Biosci. 2014, 4, 33. [CrossRef] [PubMed]

6. Schussler, J.R.; Brenner, M.L.; Brun, W.A. Abscisic Acid and its relationship to seed filling in soybeans. Plant Physiol. 1984, 76, 301-306. [CrossRef] [PubMed]

7. Möller, B.; Weijers, D. Auxin Control of Embryo Patterning. Cold Spring Harb. Perspect. Biol. 2009, 1, a001545. [CrossRef] [PubMed]

8. Venglat, P.; Xiang, D.; Wang, E.; Datla, R. Genomics of seed development: Challenges and opportunities for genetic improvement of seed traits in crop plants. Biocatal. Agric. Biotechnol. 2014, 3, 24-30. [CrossRef]

9. Mizutani, M.; Naganuma, T.; Tsutsumi, K.; Saitoh, Y. The syncytium-specific expression of the Orysa;KRP3 CDK inhibitor: Implication of its involvement in the cell cycle control in the rice (Oryza sativa L.) syncytial endosperm. J. Exp. Bot. 2010, 61, 791-798. [CrossRef] [PubMed]

10. Jong, A.D.; Koerselmankooij, J.W.; Schuurmans, J.; Borstlap, A.C. The Mechanism of Amino Acid Efflux from Seed Coats of Developing Pea Seeds as Revealed by Uptake Experiments. Plant Physiol. 1997, 114, 731-736. [CrossRef] [PubMed]

11. Weber, H.; Borisjuk, L.; Wobus, U. Molecular physiology of legume seed development. Annu. Rev. Plant Biol. 2005, 56, 253-279. [CrossRef] [PubMed]

12. Guilfoyle, T.J.; Hagen, G. Auxin response factors. Curr. Opin. Plant Biol. 2007, 10, 453-460. [CrossRef] [PubMed]

13. Zouine, M.; Fu, Y.; Chateignerboutin, A.L.; Mila, I.; Frasse, P.; Wang, H.; Audran, C.; Roustan, J.P.; Bouzayen, M. Characterization of the Tomato ARF Gene Family Uncovers a Multi-Levels Post-Transcriptional Regulation Including Alternative Splicing. PLoS ONE 2014, 9, e84203. [CrossRef] [PubMed]

14. Tiwari, S.B.; Hagen, G.; Guilfoyle, T. The Roles of Auxin Response Factor Domains in Auxin-Responsive Transcription. Plant Cell 2003, 15, 533-543. [CrossRef] [PubMed]

15. Okushima, Y.; Mitina, I.; Quach, H.L.; Theologis, A. Auxin response factor 2 (ARF2): A pleiotropic developmental regulator. Plant J. 2010, 43, 29-46. [CrossRef] [PubMed]

16. Ellis, C.M.; Nagpal, P.; Young, J.C.; Hagen, G.; Guilfoyle, T.J.; Reed, J.W. Auxin response factor 1 and Auxin response factor 2 regulate senescence and floral organ abscission in Arabidopsis thaliana. Development 2005, 132, 4563-4574. [CrossRef] [PubMed]

17. Schruff, M.C.; Spielman, M.; Tiwari, S.; Adams, S.; Fenby, N.; Scott, R.J. The AUXIN RESPONSE FACTOR 2 gene of Arabidopsis links auxin signalling, cell division, and the size of seeds and other organs. Development 2006, 133, 251-261. [CrossRef] [PubMed] 
18. Wang, L.; Hua, D.; He, J.; Duan, Y.; Chen, Z.; Hong, X.; Gong, Z. Auxin Response Factor2 (ARF2) and Its Regulated Homeodomain Gene HB33 Mediate Abscisic Acid Response in Arabidopsis. PLoS Genet. 2011, 7, e1002172. [CrossRef] [PubMed]

19. Chen, Q.F. Seed proteins of buckwheat. In Buckwheat Plant Science; Du, M.F., Fan, Y., Eds.; Science Press: Beijing, China, 2012.

20. Liu, D.S.; Xu, R.Y.; Wang, Q.Q. Analysis of protein content and Amino Acid composition in Buckwheat. Chin. Seed ind. 1997, 2, 26-28.

21. Lin, R.F. Tartary buckwheat. Agrotechny 2013, 21, 41.

22. Jain, M.; Kaur, N.; Tyagi, A.K.; Khurana, J.P. The auxin-responsive GH3 gene family in rice (Oryza sativa). Funct. Integr. Genom. 2006, 6, 36-46. [CrossRef] [PubMed]

23. Hagen, G.; Guilfoyle, T. Auxin-responsive gene expression: Genes, promoters and regulatory factors. Plant Mol. Biol. 2002, 49, 373-385. [CrossRef] [PubMed]

24. Liscum, E.; Reed, J.W. Genetics of Aux/IAA and ARF action in plant growth and development. Plant Mol. Biol. 2002, 49, 387-400. [CrossRef] [PubMed]

25. Chojecki, A.J.S.; Bayliss, M.W.; Gale, M.D. Cell Production and DNA Accumulation in the Wheat Endosperm, and their Association with Grain Weight. Ann. Bot. 1986, 58, 809-817. [CrossRef]

26. Chojecki, A.J.S.; Gale, M.D.; Bayliss, M.W. The Number and Sizes of Starch Granules in the Wheat Endosperm, and their Association with Grain Weight. Ann. Bot. 1986, 58, 819-831. [CrossRef]

27. Munier-Jolain, N.G.; Ney, B. Seed growth rate in grain legumes II. Seed growth rate depends on cotyledon cell number. J. Exp. Bot. 1998, 49, 1971-1976. [CrossRef]

28. Perrot-Rechenmann, C. Cellular responses to auxin: Division versus expansion. Cold Spring Harb. Perspect. Biol. 2010, 2, a001446. [CrossRef] [PubMed]

29. Chapman, E.J.; Estelle, M. Mechanism of auxin-regulated gene expression in plants. Annu. Rev. Genet. 2009, 43, 265-285. [CrossRef] [PubMed]

30. Huang, K.F.; Peng, H.R.; Guo, X.; Zhao, G.; Chen, Q.F. Differences of Endogenous hormones in two Tartary Buckwheat cultivars at maturity and their relationship with yield and quality. Jiangsu J. Agric. 2013, 29, $28-32$.

31. Qin, P.Y. Evaluation of the Resources and quality of main Buckwheat varieties in China and the effect of processing on the composition and activity of Buckwheat. Chin. Acad. Agric. Sci. 2012, 1, 265-285.

32. Yang, X.; Ren, Z.X.; Lin, D.B.; Xian, Z.Q.; Li, Z.G. Expression pattern of SLARF2 Gene in Tomato and its function Analysis in Fruit Development. J. Trop. Crop 2014, 35, 1969-1974.

33. Mei, Z.; Bing, Y.; Ping, L. The role of ABA in triggering ethylene biosynthesis and ripening of tomato fruit. J. Exp. Bot. 2009, 60, 1579-1588.

34. Ofosu-Anim, J.; Kanayama, Y.; Yamaki, S. Sugar uptake into strawberry fruit is stimulated by abscisic acid and indoleacetic acid. Physiol. Plant. 2010, 97, 169-174. [CrossRef]

35. Manning, K. Changes in gene expression during strawberry fruit ripening and their regulation by auxin. Planta 1994, 194, 62-68. [CrossRef]

36. Jiang, Y.; Joyce, D.C. ABA effects on ethylene production, PAL activity, anthocyanin and phenolic contents of strawberry fruit. Plant Growth Regul. 2003, 39, 171-174. [CrossRef]

37. Kano, Y.; Asahira, T. Roles of Cytokinin and Abscisic Acid in the Maturing of Strawberry Fruits. J. Jpn. Soc. Hort. Sci. 1981, 50, 31-36. [CrossRef]

38. Finkelstein, R.R.; Gampala, S.S.; Rock, C.D. Abscisic acid signaling in seeds and seedlings. Plant Cell 2002, 14, S15. [CrossRef] [PubMed]

39. Wang, H.; Qi, Q.; Schorr, P.; Cutler, A.J.; Crosby, W.L.; Fowke, L.C. ICK1, a cyclin-dependent protein kinase inhibitor from Arabidopsis thaliana interacts with both Cdc2a and CycD3, and its expression is induced by abscisic acid. Plant J. 2010, 15, 501-510. [CrossRef]

40. Guilfoyle, T.J. Auxin-regulated genes and promoters. New Compr. Biochem. 1999, 33, 423-459.

41. Guilfoyle, T.J.; Gretchen, H. Auxin response factors: Recent advances in auxin biology. J. Plant Growth Regulat. 2001, 3, 317-319.

42. Guilfoyle, T.J. Aux/IAA proteins and auxin signal transduction. Trends Plant Sci. 1998, 3, 205-207. [CrossRef]

43. Jameson, P.E.; Song, J. Cytokinin: A key driver of seed yield. J. Exp. Bot. 2015, 67, 593-606. [CrossRef] [PubMed]

44. Gil, P.; Liu, Y.; Poff, K.L.; Green, P.J. Characterization of the Auxin-Inducible SAUR-AC1 Gene for Use as a Molecular Genetic Tool in Arabidopsis. Plant Physiol. 1994, 104, 777-784. [CrossRef] [PubMed] 
45. Roux, C.; Bilang, J.; Theunissen, B.H.; Perrot-Rechenmann, C. Identification of new early auxin markers in tobacco by mRNA differential display. Plant Mol. Biol. 1998, 37, 385-389. [CrossRef] [PubMed]

46. Guilfoyle, T.J.; Hagen, G.; Li, Y.; Ulmasov, T.; Liu, Z.B.; Strabala, T.; Gee, M. Auxin-Regulated Transcription. Funct. Plant Biol. 1993, 20, 489-502. [CrossRef]

47. Mcclure, B.A.; Guilfoyle, T. Characterization of a class of small auxin-inducible soybean polyadenylated RNAs. Plant Mol. Biol. 1987, 9, 611-623. [CrossRef] [PubMed]

48. Kong, Y.; Zhu, Y.; Gao, C.; She, W.; Lin, W.; Chen, Y.; Han, N.; Bian, H.; Zhu, M.; Wang, J. Tissue-specific expression of SMALL AUXIN UP RNA41 differentially regulates cell expansion and root meristem patterning in Arabidopsis. Plant Cell Physiol. 2013, 54, 609-621. [CrossRef] [PubMed]

49. Kant, S.; Rothstein, S. Auxin-responsive SAUR39 gene modulates auxin level in rice. Plant Signal. Behav. 2009, 4, 1174-1175. [CrossRef] [PubMed]

50. Tian, Q.; Reed, J.W. Arabidopsis SHY2/IAA3 inhibits auxin-regulated gene expression. Plant Cell 2002, 14, 301-319. [CrossRef] [PubMed]

51. Khan, S.; Stone, J. Arabidopsis thaliana GH3.9 influences primary root growth. Planta 2007, 226, 21-34. [CrossRef] [PubMed]

52. $\mathrm{Xu}, \mathrm{X}$. The Role of Gibberellin, Abscisic Acid, and Sucrose in the Regulation of Potato Tuber Formation In Vitro. Plant Physiol. 1998, 117, 575-584. [CrossRef] [PubMed]

53. Baydar, H.; Ulger, S. Correlations Between Changes in the Amount of Endogenous Phytohormones and Flowering in the Safflower (Carthamus tinctorius L.). Turk. J. Biol. 2014, 22, 421-426.

54. Mwange, K.N.; Hou, H.W.; Cui, K.M. Relationship between endogenous indole-3-acetic acid and abscisic acid changes and bark recovery in Eucommia ulmoides Oliv. after girdling. J. Exp. Bot. 2003, 54, 1899-1907. [CrossRef] [PubMed]

55. Kumar, R.; Tyagi, A.K.; Sharma, A.K. Genome-wide analysis of auxin response factor (ARF) gene family from tomato and analysis of their role in flower and fruit development. Mol. Genet. Genom. 2011, 285, 245-260. [CrossRef] [PubMed]

56. Kenneth, J.L.; Schmittgen, T.D. Analysis of Relative Gene Expression Data Using RT-qPCR. Methods 2001, 25, 402-408. 